\title{
MANAJEMEN EKSTRAKURIKULER DAN KONTRIBUSINYA TERHADAP KECERDASAN SISWA DI MADRASAH TSANAWIYAH NEGERI (MTSN) KOTA SAWAHLUNTO
}

\author{
Marzuan \\ Kepala Madrasah Ibtidaiyyah Negeri 3 Kota Sawahlunto \\ e-mail: s.marzuan@yahoo.co.id \\ $+20$
}

\begin{abstract}
This study aims to determine the extracurricular management and its contribution to the students' intelligence in Madrasah Tsanawiyah Negeri of Sawahlunto. The method used in this research is field research with qualitative descriptive approach. Data collection techniques used are by observation, interview and documentation. The results showed that extracurricular activities contribute to the formation of the characters and intelligence of the students in MTsN Sawahlunto, in which every extracurricular activity gives positive effect to the students. The students are able to show the good characters in everyday social process both at school and community.
\end{abstract}

Keywords: Management, Extracurricular activity, Intelligence, MTsN Sawahlunto

\section{PENDAHULUAN}

Kegiatan ekstrakurikuler bagi kalangan siswa biasa disingkat sebagai "ekskul" merupakan kegiatan penunjang kegiatan intrakurikuler. Kegiatan ekstrakurikuler merupakan kegiatan pendidikan di luar mata pelajaran dan di luar layanan konseling untuk membantu pengembangan para siswa. Ekstrakurikuler adalah "pelajaran atau pendidikan tambahan di luar kurikulum/rencana pelajaran" (Dahlan, 2001). Dalam lengkap Bahasa Indonesia, ekstrakurikuler adalah "berada di luar program, tidak termasuk progarm khusus, progaram tambahan". Sedangkan menurut Sulistyorini ekstrakurikuler adalah "kegiatan yang dilakukan di sekolah Islam, namun dalam pelaksanaannya berada di luar jam pelajaran resmi di kelas". Artinya di luar jam-jam pelajaran yang tercantum dalam jadwal pelajaran. "Kegiatan ekstrakurikuler ditujukan agar siswa dapat memperkaya dan memperluas wawasan pengetahuan, mendorong pembinaan nilai dan sikap demi untuk mengembangkan minat dan bakat siswa" (Sulistyorini, 2006).

Oleh sebab itu, kegiatan ektrakurikuler dapat berfungsi sebagai wadah penyaluran hobi, minat, dan bakat para siswa secara positif yang dapat mengasah kemampuan, daya kreativitas, jiwa sportivitas, dan meningkatkan rasa percaya diri dan lain- 
lain. Akan lebih baik lagi bila kegiatan ini mampu memberikan prestasi gemilang di luar sekolah, sehingga dapat mengharumkan nama sekolah. Pada suatu satuan pendidikan menengah lazim terdapat daftar kegiatan ekstrakurikuler semisal dalam bidang keolahragaan, bidang keagamaan/ kerohanian, bidang kesenian, bidang kepramukaan, dan lain-lain.

Siswa selaku pihak yang mendapatkan layanan pembelajaran oleh setiap warga madrasah, sebagaimana dalam kegiatan ekstrakurikuler pada Madrasah Tsanawiyah, diharapkan dapat menjalani aktivitas ekstrakurikuler dengan sungguh-sungguh agar mencapai hasil sebagaimana diprogramkan di madrasah. Pada dasarnya pendidikan memberikan bimbingan dan tuntunan kepada seseorang untuk meningkatkan kualitas dirinya dan perannya dalam masyarakat (Azis, 2010). Oleh karena itu dengan peningkatan kualitas tersebut juga harus diimbangi dengan hasil ekstrakurikuler yang baik dari jam sekolah maupun di luar jam sekolah. Hal itu mendorong siswa untuk mengikuti kegiatan luar sekolah yakni kegiatan ekstrakurikuler untuk mendapatkan hasil belajar yang memuaskan. Menurut Nana Sudjana, dalam memberikan penilaian hasil belajar juga memperhatikan sasaran pokok yang salah satunya menyangkut sikap, minat, perhatian, keterampilan siswa sebagai akibat dari proses mengajar dan belajar (Sudjana, 2009).

Menurut Basriham selaku pembina keagamaan MTsN Sawahlunto, mengatakan bahwa "siswa yang aktif mengikuti kegiatan ekstrakurikuler rata-rata mempunyai prestasi di kelasnya, namun mereka mempunyai kemampuan bersosialisasi yang baik dibandingkan dengan siswa yang tidak ikut ekstrakurikuler serta secara mental mereka menjadi lebih berani".

Kegiatan ekstrakurikuler yang ada di MTsN Sawahlunto beranekaragam. Dalam hal ini tujuan dari kegiatan ekstrakurikuler di sekolah adalah untuk meningkatkan keterampilan yang ada pada diri siswa. Sedangkan menurut Kristian Chan selaku koordinator BP/BK mengatakan "ekstrakurikuler bertujuan agar siswa memiliki kemampuan di luar akademik dan untuk meningkatkan kecerdasan bagi siswa untuk berkreasi. Sedangkan menurut Suzanna Fizianti selaku Wakil Kurikulum mengatakan "kegiatan ekstrakurikuler di MTsN Sawahlunto terdiri dari kegiatan pramuka, Drumband, Qasidah, kaligrafi dan lain sebagainya. Dari keanekaragaman kegiatan ekstrakurikuler yang ada di MTsN Sawahlunto, Penulis sengaja memfokuskan penelitian ini pada bidang pramuka dan bidang keagamaan karena kedua bidang ini mempunyai kelebihan-kelebihan yang dapat menunjang meningkatnya hasil belajar serta karier siswa di masa depan.

\section{KAJIAN TEORITIK}

\section{Manajemen}

Pada mulanya manajemen belum dapat dikatakan sebagai teori karena teori harus terjadi atas konsep-konsep yang secara sistematis 
dapat menjelaskan dan meramalkan apa yang terjadi dalam pembuktian. Setelah beberapa zaman dipelajari, manajemen telah memenuhi persyaratan sebagai bidang pengetahuan yang secara sistematis berusaha memahami mengapa dan bagaimana orang bekerja sama. Oleh karena itu kita perlu memahami hal-hal yang berhubungan dengan manajemen, di antaranya yaitu: Manajemen berasal dari kata to manage yang artinya mengatur. Pengaturan dilakukan melalui proses dan diatur berdasarkan urutan dari fungsi-fungsi manajemen itu. Jadi, manajemen itu merupakan suatu proses untuk mewujudkan tujuan yang diinginkan. Di bawah ini dijelaskan beberapa pendapat yang menjelaskan tentang pengertian manajemen. Manajemen adalah ilmu dan seni mengatur proses pemanfaatan sumber daya manusia dan sumber-sumber lainnya secara efektif dan efisien untuk mencapai suatu tujuan tertentu. (Malayu, 2007).

Istilah manajemen memiliki berbagai pengertian. Secara universal manajemen adalah penggunaan sumberdaya organisasi untuk mencapai sasaran dan kinerja yang tinggi dalam berbagai tipe organisasi profit maupun non profit. Definisi manajemen yang dikemukakan oleh Daft (2003) sebagai berikut: "Management is the attainment of organizational goals in an effective and efficient manner through planning organizing leading and controlling organizational resources". Pendapat tersebut kurang lebih mempunyai arti bahwa manajemen merupakan pencapaian tujuan organisasi dengan cara yang efektif dan efisien lewat perencanaan pengorganisasian pengarahan dan pengawasan sumberdaya organisasi.

Plunket dkk. (2005) mendefinisikan manajemen sebagai "One or more managers individually and collectively setting and achieving goals by exercising related functions (planning organizing staffing leading and controlling) and coordinating various resources (information materials money and people)". Pendapat tersebut kurang lebih mempunyai arti bahwa manajemen merupakan satu atau lebih manajer yang secara individu maupun bersama-sama menyusun dan mencapai tujuan organisasi dengan melakukan fungsi-fungsi terkait (perencanaan pengorgnisasian penyusunan staf pengarahan dan pengawasan) dan mengkoordinasi berbagai sumber daya (informasi material uang dan orang). Manajer sendiri menurut Plunket dkk. (2005) merupakan people who are allocate and oversee the use of resources jadi merupakan orang yang mengatur dan mengawasi penggunaan sumber daya.

Lewis dkk. (2004) mendefinisikan manajemen sebagai: "the process of administering and coordinating resources effectively and efficiently in an effort to achieve the goals of the organization." Pendapat tersebut kurang lebih mempunyai arti bahwa manajemen merupakan proses mengelola dan mengkoordinasi sumber daya-sumber daya secara efektif dan efisien sebagai usaha utk mencapai tujuan organisasi.

Menurut Mary Parker Follet yg dikutip oleh Handoko (2000) manajemen merupakan seni dalam menyelesaikan pekerjaan melalui orang lain. Definisi ini mengandung arti 
bahwa para manajer mencapai tujuan-tujuan organisasi melalui pengaturan orang-orang lain utk melaksanakan berbagai tugas yang mungkin diperlukan.

Jadi manajemen adalah suatu proses yang dilakukan agar suatu usaha dapat berjalan dengan baik memerlukan perencanaan, pemikiran, pengarahan, dan pengaturan serta mempergunakan semua potensi yang ada baik personal maupun material secara efektif dan efisiensi.

\section{Ekstrakurikuler}

Pasal 3 Undang-Undang Nomor 20 Tahun 2003 tentang Sistem Pendidikan Nasional menyebutkan bahwa pendidikan nasional bertujuan untuk berkembangnya potensi peserta didik agar menjadi manusia yang beriman dan bertakwa kepada Tuhan Yang Maha Esa, berakhlak mulia, sehat, berilmu, cakap, kreatif, mandiri, dan menjadi warga negara yang demokratis serta bertanggung jawab.

Pengembangan potensi peserta didik sebagaimana dimaksud dalam tujuan pendidikan nasional tersebut dapat diwujudkan melalui kegiatan ekstrakurikuler yang merupakan salah satu kegiatan dalam program kurikuler. Kegiatan ekstrakurikuler adalah program kurikuler yang alokasi waktunya tidak ditetapkan dalam kurikulum. Jelasnya bahwa kegiatan ekstrakurikuler merupakan perangkat operasional (supplement dan complements) kurikulum, yang perlu disusun dan dituangkan dalam rencana kerja tahunan/kalender pendidikan satuan pendidikan.

Kegiatan ekstrakurikuler menjembatani kebutuhan perkembangan peserta didik yang berbeda; seperti perbedaan sense akan nilai moral dan sikap, kemampuan, dan kreativitas. Melalui partisipasinya dalam kegiatan ekstrakurikuler peserta didik dapat belajar dan mengembangkan kemampuan berkomunikasi, bekerja sama dengan orang lain, serta menemukan dan mengembangkan potensinya. Kegiatan ekstrakurikuler juga memberikan manfaat sosial yang besar.

Pendidikan adalah usaha sadar yang dilakukan manusia untuk mengembangkan potensi manusia lain atau memindahkan nilai dan norma yang dimilikinya kepada orang lain dan masyarakat. Proses pemindahan nilai dan norma itu dapat dilakukan dengan berbagai cara diantaranya adalah pertama, melalui pengajaran; kedua, melalui pelatihan; ketiga, melalui indroktrinasi (Ali, 2000)

Kalau dilihat pendapat di atas, maka belajar adalah suatu proses memanusiakan manusia, dimana hanya melalui belajar manusia dapat menemukan dirinya dalam relasinya dengan sesama, lingkungan dan penciptanya. Melalui belajar manusia mengaktualisasikan dirinya dengan lingkungannya sedemikian rupa sehingga kualitas hidup dan kehidupannya menjadi makin baik.

Dari pernyataan di atas, menunjukkan bahwa untuk memanusiakan manusia diperlukan adanya pendidikan. Pendidikan pada hakekatnya bukan hanya menjadi 
tanggung jawab sekolah, tetapi juga menjadi tanggung jawab keluarga dan masyarakat. Mengenai pendidikan di sekolah, maka proses pendidikannya tertuang dalam satuan pendidikan yang lebih dikenal dengan sebutan kurikulum.

Selanjutnya, kegiatan pendidikan yang didasarkan pada penjatahan waktu bagi masing-masing mata pelajaran sebagaimana tercantum dalam kurikulum sekolah lebih kita kenal dengan sebutan kurikuler. Sedangkan kegiatan yang diselenggarakan di luar jam pelajaran tatap muka, dilaksanakan di sekolah atau diluar sekolah agar lebih memperkaya dan memperluas wawasan pengetahuan dan kemampuan yang telah dipelajari dari berbagai mata pelajaran dalam kurikulum disebut kegiatan ekstrakurikuler (Suryosubroto, 1997).

Jadi, kegiatan ekstrakurikuler adalah kegiatan yang dilaksanakan oleh guru dan siswa diluar jam sekolah yang telah di tentukan berdasarkan kurikulum yang berlaku. Kegiatan ini juga di maksudkan untuk lebih mengaitkan pengetahuan yang diperoleh dalam program kurikuler dengan keadaan dan kebutuhan lingkungan. Kegiatan ini di samping di laksanakan di sekolah, dapat juga dilaksanakan diluar sekolah guna memperkaya dan memperluas wawasan pengetahuan atau kemampuan, meningkatkan nilai sikap dalam rangka penerapan pengetahuan dan ketrampilan yang telah dipelajari dari berbagai mata pelajaran dan kurikulum sekolah.
Penyusunan program ekstrakulikuler adalah suatu aktifitas yang di maksud memilih kegiatan-kegiatan yang sudah didefinisi sesuai dengan langkah kebijakan. Pemilihan demikian harus dilakukan karena tidak semua kegiatan yang diidentifikasi tersebut nantinya dapat dilaksanakan dengan baik, penyusunan program berarti seleksi atas kegiatan-kegiatan yang sudah diidentifikasi dalam kebijakan (Imron, 2011).

Menurut Tholib Kasan, Program ekstra ini harus lebih ditujukan kepada kegiatan yang sifatnya kelompok sehingga kegiatan itu pun didasarkan atas pilihan siswa. Hal-hal yang perlu diperhatikan dalam manajemen ekstrakurikuler yaitu peningkatan aspek pengetahuan sikap dan keterampilan, dorongan untuk menyalurkan bakat dan minat siswa, penetapan waktu dan obyek kegiatan yang disesuaikan dengan kondisi lingkungan, dan jenis-jenis kegiatan ekstrakurikuler yang dapat disediakan seperti pramuka, olahraga, dan sebagainya (Kasan, 2007). Menurut Arikunto $S$ yang di maksud dengan program ekstrakulikuler ialah sederetan kegiatan yang akan dilaksanakan untuk mencapai tujuan tertentu.

Program tidak terlepas dari strategi utama sekolah/Madrasah yang telah ditetapkan sebelumnya. Rencana program meliputi program kerja untuk mengimplementasikan sasaran sebagai mana yang dimaksud oleh kebijakan organisasi. Maka rancangan program didasarkan atas visi, misi, tujuan, 
sasaran, dan kebijaksanaan yang ada hubungannya dengan segala aspek. Program adalah unsur pertama yang harus ada demi terciptanya suatu kegiatan.

\section{Kecerdasan/Inteligensi}

Kecerdasan/inteligensi berasal dari bahasa Latin "intelligence" yang berarti menghubungkan atau menyatukan satu sama lain (to organize, to relate, to bind together) (Wardianan, 2004). Pengertian inteligensi memberikan bermacam- macam arti bagi para ahli yang meneliti. Menurut mereka, kecerdasan merupakan sebuah konsep yang bisa diamati tetapi menjadi hal yang paling sulit untuk didefinisikan. Hal ini terjadi karena inteligensi tergantung pada konteks atau lingkungannya. Berikut ini beberapa ahli psikologi yang mencoba memberikan pengertian tentang inteligensi. Alfred Binet adalah seorang tokoh perintis pengukuran inteligensi, beliau menjelaskan bahwa inteligensi merupaka:

a. Kemampuan mengarahkan pikiran atau mengarahkan tindakan, artinya individu mampu menetapkan tujuan untuk dicapainya (goal setting).

b. Kemampuan untuk mengubah arah tindakan bila dituntut demikian, artinya individu mampu melakukan penyesuaian diri dalam lingkungan tertentu

c. Kemampuan untuk mengkritik diri sendiri atau melakukan auto kritik, artinya individu mampu melakukan perubahan atas kesalahan-kesalahan yang telah diperbuatnya atau mampu mengevaluasi diri sendiri secara objektif.

Edward Lee Thorndike (1874-1949), psikolog Amerika Serikat mengklasifikasikan kecerdasan menjadi tiga tipe, yaitu kecerdasan riil (concrete intellegence), kecerdasan abstrak (abstract intellegence) dan kecerdasan sosial (social intellegence).

Pertama, kecerdasan riil. Kecerdasan riil adalah kemampuan individu untuk menghadapi situasi-situasi dan benda-benda riil. Kedua, kecerdasan abstrak. Kecerdasan abstrak adalah kemampuan manusia untuk mengerti kata-kata, bilangan-bilangan, huruf- huruf, simbol- simbol, rumusrumus dan lain-lain. Ketiga, kecerdasan sosial. Kecerdasan sosial adalah kemampuan individu untuk menghadapi dan mereaksi situasi-situasi sosial atau hidup di masyarakat. Kecerdasan sosial bukan emosi seseorang terhadap orang lain, melainkan kemampuan seseorang untuk mengerti kepada orang lain, dapat berbuat sesuatu dengan tuntutan masyarakat. Individu dengan kecerdasan sosial yang tinggi akan mampu berinteraksi, bergaul atau berkomunikasi dengan orang lain secara mudah, mampu menyesuaikan diri dalam berbagai lingkungan sosial budaya.

Raymond Bernard Cattel mengklasifikasikan kemampuan mental menjadi dua macam, yaitu inteligensi fluid ( $g f)$ dan inteligensi crystallized $(g c)$. Inteligensi fluid merupakan kemampuan yang berasal dari faktor bawaan biologis 
yang diperoleh sejak kelahirannya dan lepas dari pengaruh pendidikan dan pengalaman. Sedangkan inteligensi crystallized merupakan kemampuan yang merefleksikan adanya pengaruh pengalaman, pendidikan dan kebudayaan dalam diri seseorang, inteligensi ini akan meningkat kadarnya dalam diri seseorang seiring dengan bertambahnya pengetahuan, pengalaman dan keterampilanketerampilan yang dimiliki oleh individu. Karakteristik dari inteligensi fluid cenderung tidak berubah setelah usia 14 atau 15 tahun, sedangkan inteligensi crystallized masih dapat terus berkembang sampai usia 30-40 tahun bahkan lebih.

Dari uraian di atas kecerdasan inilah yang sekarang mulai dikembangkan oleh sekolah-sekolah. Pada penelitian ini kita akan membahas tentang kecerdasan riil dan sosial yang merupakan landasan dasar dalam kecerdasan ekstrakurikuler.

Menurut teorinya kecerdasan sosial mempunyai tiga dimensi utama, yaitu social insight, social sensitivity dan social communication.

a. Social Insight, yaitu kemampuan anak untuk memahami dan mencari pemecahan masalah yang efektif dalam suatu interaksi sosial, sehingga masalahmasalah tersebut tidak menghambat apalagi menghancurkan relasi sosial yang telah dibangun anak. Tentu saja pemecahan masalah yang ditawarkan adalah pendekatan menang-menang atau win-win solution. Pondasi dasar dari social insight ini adalah berkembangnya kesadaran diri anak secara baik. Kesadaran diri yang berkembang ini akan membuat anak mampu memahami keadaan dirinya baik keadaan internal maupun eksternal.

b. Social Sensitivity atau sensitivitas sosial yaitu kemampuan anak untuk mampu merasakan dan mengamati reaksi-reaksi atau perubahan orang lain yang ditunjukkannya baik secara verbal maupun non verbal. Anak yang memiliki sensitivitas sosial yang tinggi akan mudah memahami dan menyadari adanya reaksi-reaksi tertentu dari orang lain, entah reaksi tersebut positif ataupun negatif Social Communication atau penguasaan keterampilan komunikasi sosial merupakan kemampuan individu untuk menggunakan proses komunikasi dalam menjalin dan membangun hubungan interpersonal yang sehat. Dalam proses menciptakan, membangun dan mempertahankan relasi sosial, maka seseorang membutuhkan sarananya. Tentu saja sarana yang digunakan adalah melalui proses komunikasi yang mencakup baik komunikasi verbal, non verbal maupun komunikasi melalui penampilan fisik. Keterampilan komunikasi yang harus dikuasai adalah keterampilan mendengarkan efektif, keterampilan berbicara efektif, keterampilan public speaking dan keterampilan menulis secara efektif. 
Berikut ini dijelaskan tentang karakteristik anak yang memiliki kecerdasan interpersonal yang tinggi, yaitu:

a. Mampu mengembangkan dan menciptakan relasi sosial baru secara efektif.

b. Mampu berempati dengan orang lain atau memahami orang lain secara total.

c. Mampu mempertahankan relasi sosialnya secara efektif sehingga tidak musnah di makan waktu dan senantiasa berkembang semakin intim/mendalam/ penuh makna.

d. Mampu menyadari komunikasi verbal maupun non verbal yang dimunculkan orang lain, atau dengan kata lain sensitif terhadap perubahan situasi sosial dan tuntutan-tuntutannya. Sehingga anak mampu menyesuaikan dirinya secara efektif dalam segala macam situasi.

e. Mampu memecahkan masalah yang terjadi dalam relasi sosialnya dengan pendekatan win-win solution, serta yang paling penting adalah mencegah munculnya masalah dalam relasi sosialnya.

f. Memiliki keterampilan komunikasi yang mencakup keterampilan mendengarkan efektif, berbicara efektif dan menulis secara efektif. Termasuk pula didalamnya mampu menampilkan penampilan fisik (model busana) yang sesuai dengan tuntutan lingkungan sosialnya.

Inteligensi/ kecerdasan orang satu dengan yang lainnya cenderung berbedabeda. Hal ini karena adanya beberapa faktor yang mempengaruhinya. Adapun faktor yang mempengaruhinya sebagai berikut (Djaalil, 2012):

a. Faktor bawaan, dimana faktor ini ditentukan oleh sifat yang di bawa sejak lahir. Batas kesanggupan atau kecakapan seseorang dalam pemecahan masalah antara lain ditentukan oleh faktor bawaan.

b. Faktor minat dan pembawaan yang khas, dimana minat mengarahkan perbuatan kepada suatu tujuan dan merupakan dorongan bagi perbuatan itu. dalam diri manusia terdapat dorongan atau motif yang mendorong manusia untuk berinteraksi dengan dunia luar, sehingga apa yang diminati oleh manusia dapat memberikan dorongan untuk berbuat lebih giat dan lebih baik.

c. Faktor pembentukan, di mana pembentukan adalah segala keadaan di luar diri seseorang yang mempengaruhi perkembangan inteligensi. Faktor pembentukan di sini dibedakan antara pembentukan sengaja, seperti yang dilakukan di sekolah dan pembentukan tidak disengaja, seperti pengaruh alam di sekitarnya.

d. Faktor kematangan, di mana tiap organ dalam tubuh manusia mengalami pertumbuhan dan perkembangan. Setiap organ manusia baik fisik maupun psikis dapat dikatakan telah matang jika ia telah tumbuh dan berkembang hingga mencapai kesanggupan menjalankan 
fungsinya masing-masing. Oleh karena itu, tidak mengherankan bila anakanak belum mampu mengerjakan atau memecahkan soal-soal matematika, karena soal-soal itu masih terlalu sukar baginya. Organ tubuhnya dan fungsi jiwanya masih belum matang untuk menyelesaikan soal tersebut dan kematangan berhubungan erat dengan umur.

e. Faktor kebebasan, yang berarti manusia dapat memilih metode tertentu dalam memecahkan masalah yang dihadapi. Disamping kebebasan memilih metode juga bebas dalam memilih masalah yang sesuai dengan kebutuhannya.

\section{METODE PENELITIAN}

Jenis penelitian ini adalah field research untuk membuktikan keadaan sebenarnya dari fenomena objek yang diteliti dan dibandingkan dengan teori yang sesuai dengan masalah ini. Penelitian ini tentang manajemen ekstrakurikuler dan kontribusinya terhadap kecerdasan siswa di MTsN Kota Sawahlunto.

Penelitian ini adalah deskriptif kualitatif menghasilkan uraian berupa kata-kata tertulis atau lisan dari pelaku para aktor yang dapat diamati dalam situasi sosial. Peneliti berusaha memahami makna yang terkandung dalam latar sosial tersebut dan untuk dapat mengungkapkan pelaku itu serta maknanya perlu dilakukan pengamatan dan wawancara dengan para aktor.
Dokumen atau arsip ini merupakan suatu cara pengumpulan data yang menghasilkan catatan-catatan penting atau bukti-bukti fisik yang berhubungan dengan yang diteliti. Karena penelitian ini berhubungan dengan Manajemen kegiaran ekstrakurikuler maka peneliti mengumpulkan dokumen dan arsip yang berkaitan dengan ekstrakurikuler seperti, absensi, program dan lain sebagainya.

\section{HASIL PENELITIAN}

Perencanaan ektsrakurikuler dalam meningkatkan kecerdasan siswa pada setiap kegiatan ektsrakurikuler di MTsN Sawahlunto selalu diawali dari perencaan yang tertuang dalam program kerja yang dibuat oleh pengurus OSIS bersama pembina ektsrakurikuler dan bimbingan Kepala Sekolah. Program kerja tersebut berorentasi pada pembetukan kecerdasan dan karakter siswa, dimana sekolah ini berprinsip bahwa dengan membentuk karakter, maka prestasi akademik akan mengikuti. Program dibuat di awal semester dengan memperhatikan potensi dan minat peserta didik. Hal ini juga dimaksudkan agar peserta didik merasa betah dan mau menjalankan program yang dibuat bersama.

Pelaksanaan ektsrakurikulerselalu dilakukan sepanjang hari, karena diyakini dengan pelaksanaan yang baik akan menghasilkan apa yang diharapkan untuk membentuk kecerdasan siswa itu. Maka dari itu dalam proses, kami menekankan adanya proses pembiasaan terhadap nilai- 
nilai yang ditanamkan, sehingga menjadi kepribadian siswa. Dan prinsip sekolah tidak dimasalahkan ketika anak mendapatkan pendidikan, tapi yang terpenting adalah bagaimana proses itu dijalankan. Guru Pembina kegiatan ektsrakurikuler MTsN Sawahlunto selalu bekerja ekstra untuk memberdayakan program ektsrakurikuler dalam menjalankan programnya. Karena guru Pembina merupakan tempat konsultasi bagi pengurus. Maka dalam pengamatan peneliti, guru Pembina ektsrakurikuler MTsN Sawahlunto selalu menjalin komunikasi intensif dengan pengurus.

Evaluasi yang dilakukan guru pembina ektsrakurikuler dalam membantu membina terwujudnya kegiatan ektsrakurikuler dalam bentuk mulai dari perencanaan program sampai proses evaluasi serta membantu mengkomunikasikan sumber dana kegiatan kepada Kepala Madrasah. Evaluasi dilakukan untuk melihat kelemahan-kelemahan serta program yang telah dilaksanakan guna menyempurkan pelaksanaan program untuk membentuk katrakter siswa. Evaluasi dilakukan dalam pemberian laporan yang dilakukan dan dibahas secara bersama-sama. Evaluasi biasanya dilakukan setiap hari senin setelah upacara bendera dilakukan. Setelah itu dilakukan musyawarah untuk mengetahui sejauhmana tujuan dari setiap program bias dicapai. Namun secara umum proses evaluasi biasa dilakukan di akhir-akhir semester, untuk menetukan perencanaan dan program yang baikpada semester baru. Acuan evalauasi tentu pada perbandingan antara perencanaan dengan hasil yang telah dicapai. Ada dari pihak Kementerian Agama, pengawas pendidikan madrasah dan komite sekolah.

Kontribusi ekstrakurikuler terhadap pembentukan kecerdasan siswa di MTsN Sawahlunto terlihat dari setiap kegiatan, memang memberikan pengaruh yang positif terhadap siswa. Karena dari setiap kegiatan, selalu diberikan target perubahan kepada siswa. Dan hal itu akan terlihat di waktu proses siswa dengan sesama siswa, siswa dengan guru, dan juga siswa dengan orang tua dan masyarakat. Di mana siswa mampu melihat karakter-karakter yang baik dalam proses pergaulannya sehari-hari di lingkungan sekolah dan masyarakat. Serta perubahan karakter juga berpengaruh terhadap cara belajar siswa.

\section{PENUTUP}

Perencanaan ektsrakurikuler dalam meningkatkan kecerdasan siswa pada setiap kegitan ektsrakurikuler di MTsN Sawahlunto selalu diawali dari perencaan yang tertuang dalam program kerja yang dibuat oleh pengurus OSIS bersama pembina ektsrakurikuler dan bimbingan Kepala Sekolah. Pelaksanaan ektsrakurikuler selalu dilakukan sepanjang hari. Sekolah meyakini dengan pelaksanaan yang baik akan menghasilkan apa yang diharapkan untuk membentuk kecerdasan siswa itu. Maka dari itu dalam proses, kami menekankan adanya proses pembiasaan terhadap nilai-nilai yang 
ditanamkan. Sehingga menjadi kepribadian siswa. Evaluasi dilakukan guru pembina ektsrakurikuler dalam membantu membina terwujudnya kegiatan ektsrakurikuler yang aktif. Mulai dari perencanaan program sampai proses evaluasi serta membantu mengkomunikasikan sumber dana kegiatan kepada Kepala Madrasah. Kontribusi ekstrakurikuler terhadap pembentukan kecerdasan siswa di MTsN Sawahlunto terlihat dari setiap kegiatan memberikan pengaruh yang positif terhadap siswa. Karena dari setiap kegiatan, selalu diberikan target perubahan kepada siswa. Dan hal itu akan terlihat diwaktu proses siswa dengan sesama siswa, siswa dengan guru, dan juga siswa dengan orang tua dan masyarakat

\section{KEPUSTAKAAN ACUAN}

Abd Aziz, 2010. Orientasi Pendidikan Agama di Sekolah, Yogyakarta: Teras.

Ahmad Hatta, 2009. Tafsir Qur'an Perkata Dilengkapi dengan Asbabunnuzul \& Tarjamah, Jakarta; Maghfirah Pustaka.

Ali Imron, 2011. Manajemen Peserta Didik Berbasis Sekolah, Jakarta; PT Bumi Aksara.

Amir Daien, 1989. Pengelolaan Kesiswaan, dalam Hendyat Soetopo, Manajemen dan Organisasi Sekolah. Malang: IKIP Malang.

Dahlan al Barry, 2001. Kamus Ilmiah Populer. Surabaya: Arkola.
Drs. H. Malayu S.P. Hasibuan, 2004. DasarDasar Perbankan. Jakarta: Bumi Aksara.

Daryanto, Administrasi Pendidikan, (Jakarta; PT Rineka Cipta)

Dr. Nana Sudjana, 2001. Penelitian dan Penilaian Pendidikan, (Bandung: Sinar Baru Algensindo, Cet.2

Em Zul Fajri dan Ratu Aprilia Senja, Kamus Lengkap Bahasa Indonesia, Aneka Ilmu bekerjasama Difa Publisher)

Eka Prihantin, 2011. Manajemen Peserta Didik, Bandung: Alfabeta.

Hasibuan, Malayu, 2005. Manajemen Dasar, Pengertian dan Masalah, PT Bumi Aksara: Jakarta.

Hasbullah, 2005. Dasar-Dasar Ilmu Pendidikan. Jakarta: PT. Raja Grafindo.

Malayu S. P. Hasibuan, 2007. Manajemen Sumber Daya Manusia. Jakarta: Bumi Aksara.

Malayu S. P. Hasibuan, 2005. Manajemen, Dasar, Pengertian dan Masalah. Jakarta: BumiAksara.

M. Ngalim Purwanto, 2008. Administrasi dan Supervisi Pendidikan. Bandung: Remaja Rosdakarya.

Malayu S. P. Hasibuan, 2005. Manajemen, Dasar, Pengertian dan Masalah. Jakarta: Bumi Aksara.

Mohammad Daud Ali, 2000. Pendidikan Agama Islam. Jakarta: PT. PT. Raja Grafindo Persada Grafindo Persada. 
Mulyono, 2008. Manajemen Administrasi dan Organisasi Pendidikan. Yogyakarta: Ar-Ruzz Media, Cet. I

Nana Sudjana, 2009. Dasar-Dasar Proses Belajar Mengajar. Bandung: Sinar Baru Algensindo.

Nanang Fatah, 2012. Sistem Penjaminan Mutu Sekolah. Bandung; PT Remaja Rosdakarya.

Popi Sopianti, 2010. Manajemen Belajar Berbasis Kepuasan Siswa. Cilegon: Ghalia Indonesia.

Prof. Dr. Lexy J. Moleong, 2006. Metodologi Penelitian Kualitatif, (Bandung: PT. Remaja Rosdakarya. Cet.22

Riduwan, 2005. Belajar Mudah Penelitian untuk Guru, Karyawan dan Peneliti Pemula. Bandung, Alfabeta.

Rahmat, Definisi Manajemen, disalin dari website: http://blog.re.or.id/definisi manajemen
Syafaruddin, 2005. Manajemen Pendidikan Islam.Jakarta: Ciputat Press.

Sulistyorini, 2006. Manajemen Pendidikan Islam. Surabaya: Elkaf.

Suryosubroto, 1997. Proses Belajar Mengajar di Sekolah. Jakarta: Rineka Cipta.

Tholib Kasan, 2007. Teori dan Aplikasi Administrasi Pendidikan. Jakarta: Studia Press.

Undang-undang RI Sistem Pendidikan Nasional (Semarang, Aneka Ilmu, 2003)

UU RI No. 20 Th. 2003. Tentang Sistem Pendidikan Nasional, (Jogjakarta: Bening, 2010)

W. Mantja, 2007. Profesionalisasi Tenaga Kependidikan, Manajemen Pendidikan dan Pengajaran. Malang: Elang Mas. 